\title{
THE IMPACT OF SUPPLY CHAIN OPERATIONAL CAPABILITY ON BUSINESS PERFORMANCE: EMPIRICAL FINDING FROM SMALL AND MEDIUM ENTERPRISES IN YOGYAKARTA
}

\author{
Danu Oki Prastia ${ }^{1}$, Siti Nursyamsiah ${ }^{2}$ \\ Department of Management, Faculty of Economics \\ Universitas Islam Indonesia \\ e-mail: danuoki206@gmail.com \\ e-mail:inung.nursyamsiah@gmail.com
}

\begin{abstract}
This study aimed to analyze the effect of supply chain capability on business performance of small and medium enterprises (SMEs) in Yogyakarta. Supply chain capability is the ability to coordinate activities related to the flow of materials and products, both of which are within the organization and between organizations. Supply chain operational capability is measured using 3 capabilities including structural, logistical and the technological capability. The sample of this study were selected using simple random method. A total of 193,391 SMEs were analysed this study and resulting 100 SMEs that were used as the subjects. Moreover, this study employed multiple regression analysis to analyse the proposed hypothesis. The results showed that simultaneously and partially operational capability of supply chain consisting of the structural, logistics and the technological capability affect the business performance of SMEs in Yogyakarta.
\end{abstract}

Keywords: SME, Supply Chain Operational Capability, Business Performance http://dx.doi.org/10.20885/jsb.vol20.iss1.art8

\begin{abstract}
Abstrak
Penelitian ini bertujuan untuk menganalisis efek kapabilitas rantai pasokan pada kinerja bisnis Usaha Mikro, Kecil, dan Menengah (UMKM) di Yogyakarta. Kapabilitas rantai pasokan adalah kapabilitas untuk mengkoordinasi aktivitas terkait arus material dan produk, keduanya berada dalam ranah organisasi dan antar organisasi. Kapabilitas rantai pasokan diukur menggunakan tiga kapabilitas meliputi kapabilitas struktural, logistikal, dan teknologikal. Sampel penelitian dipilih menggunakan metode acak sederhana. Total 193.391 UMKM dianalisis di riset ini dan menghasilkan 100 UMKM yang digunakan sebagai subjek penelitian. Lebih lanjut, penelitian ini menguji hipotesis dengan analisis regresi berganda. Hasil menunjukkan bahwa baik secara parsial maupun simultan, kapabilitas operasional yang meliputi struktural, logistikal, dan teknologikal berpengaruh pada kinerja bisnis UMKM di Yogyakarta.
\end{abstract}

Kata Kunci: UMKM, Kapabilitas Operasional Rantai Pasokan, Kinerja Bisnis

\section{INTRODUCTION}

The rapid development of information, communications, technology and manufacturing process resulted in the short-life cycle of the products. Therefore, every company will do everything possible to improve their productivity, efficiency, and services to be faster, easier, and also continue to create new innovations to keep being superior and prefential and to survive in the market. In addition to productivity and efficiency which needs to be improved, the company must also understand and know what is needed by the consumer. Due to the intense competition and the change occurred on the business environment these days, the market demands a new model in the management of the flow of products / information particularly on marketing the product, which is a modification of a previous method (logistics management), the Supply Chain Management (SCM).

According to Levi, et.al (2000) SCM is an approach used to achieve a more efficient integration of suppliers, manufacturers, distrib- 
utors, retailers and customers. It means that the goods are produced in the right quantity, at the right time and at the right place with the aim of achieving the cost of the overall minimum system and also achieve the desired service level. SCM is able to cope with the supply problems in a state that the product is available and suitable for consumption.

One industry group that requires the implementation of SCM the Small and Medium Enterprises (SMEs). The types of SMEs in developing countries have reached $30 \%-60 \%$ of the total types of businesses. In Indonesia alone, the total types of the SMEs are about 37\%-43\% in Java and $40 \%-50 \%$ in the outer (Sriyana, 2010). Meanwhile, the main problem of SMEs is that there is still existence of unstable financial and the difficulty of finding a loan. The procurement of raw materials also becomes a problem due to the high price of raw materials. The high cost of raw materials ranked the largest in the burden of the costs of SMEs in the amount of $32 \%$, while labor and fuel of each only need $23 \%$ and $21 \%$ (Sriyana, 2010).

SMEs must be managed properly and neatly, thus that kind of problem does not arise again. SMEs are also expected to be able to get better counseling or business services, so that it can access financing, marketing, and raw materials with ease. On the other hand, SMEs need a serious integration of the planning process of ordering and sales. In the world of competition, the implementation of SCM (SCM) can reduce the cost effects of the competition in the market.

The principles of SCM (SCM) is essentially the synchronization and the coordination of activities related to the flow of materials and products, both of which are within the organization and between the organizations. The flow of materials / products in one organization, for example the manufacturing industry, is complex. It requires the intervention of all parties, not just those who are directly traversed by the flow of materials / products physically, but also other parts such as product design, marketing, accounting, and many others.

The approach of SCM are well aware that the vast majority of an industrial business should be done on the basis of cooperation with external parties. The raw materials oftenly become a major component of production cost which was obtained from the suppliers (outsiders). Meanwhile, the payments of business transactions require the services of a third party, namely banking intermediation. The delivery of raw materials from suppliers as well as the finished products to the distributors often use the services of the third party. The technology and information systems may also be provided and maintained by the third parties. Consequently, only companies that are able to establish and maintain the relationships with the outside parties that can survive strongly in the market competition. Based on these problems, this study was conducted to determine the influence of supply chain operational capability of the business performance of SMEs in Yogyakarta.

\section{LITERATURE REVIEW}

\section{Supply Chain Management}

According Heizer and Render (2005), the SCM is covering the entire interaction between suppliers, manufacturers, distributors, and consumers. This interaction is also associated with the transport, scheduling information, credit and cash transfers, as well as the transfer of raw materials between the parties involved.

The SCM (SCM) is a strategic consideration in order to obtain a competitive advantage. The SCM policy will significantly affect the company's operations as well as other operating strategies. Indrajit and Djokopranoto (2002) elaborated the activities that can be done in support of SCM, which are, to develop the relationship of partnership with he organizations upstream and downstream, to seek the information flow both upstream and downstream accurately and on time, while in the logistics field, it can be done through giving the supply of goods whenever necessary, a quick delivery in accordance with orders, the raw material procurement functions in accordance with the demand for the products, and the distribution strategy which should be done effectively and efficiently.

Traditionally, the marketing, distribution, planning, manufacturing processes, and the purchasing function along the supply chain is operated separately. Each piece has a specific target so that it tends to generate the conflicts among every sections. Meanwhile, the target marketing of the high service given to the consumers and the maximization of the sales often collide with the importance of manufacturing fields and distribution purposes. Many manu- 
facturing operations are designed to maximize the output and to low the cost with a little consideration of the impact on the level of inventory or distribution capabilities.

Moreover, the purchase contracts are often negotiated with the information about the limited historical purchasing patterns. Therefore, we need a plan which is integrated into a single purpose and unity, i.e customer satisfaction. The SCM is a strategy to achieve the integration of this kind, so that the coordination among every sections in a chain can be the key to effective management of SCM.

\section{Why Small and Medium Enterprises?}

The Central Bureau of Statistics, in Sriyana (2010), defines Micro Bussiness as a business which has a workforce of more than 4 people. Whereas, the Small Business based on Act No. 9 of 1995 is the small-scale productive business which meet the criteria of net worth at most IDR 200,000,000 (two hundred million rupiahs) not including the land and buildings of business place, or which have sales revenue at most IDR 1,000,000,000 (one billion rupiahs) per year and can receive credit from the bank maximumly above IDR 50,000,000 (fifty million rupiahs) up to IDR 500,000,000 (five hundred million rupiahs).

The World Bank, in Sriyana (2010), defines a Small Business or Small Enterprise, with the following criteria: the number of employees is less than 30 people; the year incomes do not exceed US\$ 3 million; and the total assets do not exceed US\$ 3 million. However, the current understanding of the Small Business, based on the Act No. 20 of 2008, it was the productive economic activities that stand alone, carried out by an individual or business entity which is not a subsidiary or not the branches of companies owned, controlled or be a part, either directly or indirectly from the medium or large businesses that have a net worth of more than IDR 50,000,000 (fifty million rupiahs) up to at most IDR 500,000,000 (five hundred million rupiahs) not including land and buildings of the business place; or have the annual sales of more than IDR 300,000,000 (three hundred million rupiah) up to at most IDR $2,500,000,000$ (two and a half billion rupiahs).

\section{The Indicators of Supply Chain Operational Capability}

There has been a large number of studies discussing operational capabilities of supply chain. In order to gain better understanding as well as to develop comprehensive constructs, this study select previous studies in this area using a systematic literature review. In systematic literature review, a number of keywords were proposed in advance and then entered into databases. Next, the selected articles were elaborated to analysed in details. According to our systematic literature review, the indicators of supply chain operational capability in the SMEs consist of three things: structural capability, logistics capability, and technological capability (Zulkifli, 2010). An explanation of each indicator is as follows:

\section{Structural Capability}

The structural capability is one of the indicators used to assess the supply chain operational capability. The structural capability is often called as the Human Resources capital or human capital. Zairi (1998) in Zulkifli (2010) emphasized that people are the most important assets in an organization, and the success of an organization depends more on the people that are inside the organization itself as compared to the products they produce.

The success of a company depends on the internal and external structure. According to Bowersox and Daugherty (1995), the internal structure is defined as "the allocation or assignment of roles and relationships within the company". This structure controls several functional tasks such as sales / marketing, accounting, manufacturing/operations and logistics; This task is derived from the ability of the company and its core competencies and is the backbone of its ability to develop a good performance.

Whereas, the external structure aims to maintain a good relationship between trading partners or suppliers with the company (Bowersox and Daugherty, 1995). Therefore, the managers of the company are encouraged to have a good knowledge of how the company collaborated with others (related parties) both inside and outside their organization. Similarly, companies also need to train their managers to direct the energy of their employees towards the desired goal and good performance (Zulkifli, 2010). 


\section{Logistics Capability}

Ellinger et al. (2000) in Zulkifli (2010) stated that there is a relationship between logistics capability and integrated performance with the other functional areas within the company, such as marketing, finance and operations. Several studies had shown that the performance and capabilities of logistics related to each other in order to develop the company's market share (Zulkifli, 2010). Meanwhile, Cho et. al (2008) found the logistics company's ability to improve performance should be supported by a third party in this case is a logistics provider, or more commonly known as a 3PL.

According to Sohail and Sohal (2003) in Zulkifli (2010), most companies are satisfied with the services provided by 3PL because it encourages a positive development in the organization. Most of those who use 3PL to enter the international market is because they provide benefits in terms of cost and delivery time. Therefore, companies should pay attention to the good logistics activities to develop a good distribution channels to prepare a coherent distribution planning and creating a smooth delivery process (Kallio, 2000 in Zulkifli, 2010). Several studies had shown the ability of logistics as a key factor in the operation of supply chain activities to gain and maintain a competitive advantage (Yong, Shi-hua, and Feng-mei, 2007).

\section{Technological Capability}

The implementation of the technology aspect is very important for every company. Thus, another focus of this paper is on the development of technological capability as a part of the supply chain operations of SMEs in Indonesia. Technological capability focuses on the productive enterprises abilities to face the technological development of industrial and technological change (Lall, 1993 in Zulkifli, 2010). Meanwhile, Zulkifli (2010) mentioned some of the factors that hinder the company related with the implementation of information and technology, which are: 1) The view of information and technology as a very cumbersome and too complex. 2) The requirement of information and technology in a substantial investment. 3) The incapacity companies in developing information and technology strategies.

In support of the previous statements, Sayuti (2007) in Zulkifli (2010) said that SMEs should focus on the development of organizational learning to continue to adopt the technology in their operating systems to be more competitive in today's global marketplace. Failure to identify the technological capability will contribute to the difficulties in developing new products or production techniques.

\section{Business Performance}

Generally, business performance can be described as the operational capability to satisfy the company's main stakeholders (Smith and Reece, 1999, in Zulkifli, 2010). Business performance should be assessed to achieve the organizational goals by the way of measuring the success or the failure and the business performance which can be defined in several ways. For example, the measurement of performance may be based on the profits, return on investment and revenues or the number of customers (Wood, 2006).

Business performance is also related with the marketing and finance field, for example, profitability, market share and sales growth (Feng et.al, 2008). Business performance can also be measured using two quality variables: the design quality and the product improvement (Laura, 1996 in Zulkifli et.al, 2010). However, there is a debate regarding the use of the return on investment (ROI) and the return to measure the financial performance. If there is a change in operations, ROI measurement will be affected and resulted in a poor performance. In the same way, the advantage is also not a good indicator to measure the performance of SMEs, which will follow the remuneration policies that reduce the income tax liability (Simpson et al., 2006 in Zulkifli, 2010).

In this study, the business performance of SMEs were assessed by the indicators developed by Mann and Kehoe (1994) which was also used by Zulkifli et.al (2010). According to Mann and Kehoe (1994) in Zulkiflie et.al (2010), business performance is categorized into two broad areas: the business strategic performance and the operational business performance. The business strategic is related with the evaluation of organizational performance in terms of the major corporate objectives, while the operational business performance is related with the daily organizational actions. 


\section{Research Framework and Hypotheses}

A study that examine the effect of operational capability in supply chain of the business performance of SMEs in Malaysia is conducted by Zulkifli (2010). The operational capabilities of the supply chain consist of three things: structural capabilities, logistics capabilities, and logistical capabilities. This study uses 1402 companies including SMEs in Malaysia. By using multiple regression, the results of this study are the operational capabilities of the supply chain consist of three things: structural capabilities, logistics capabilities, and technological capabilities which have a significant effect on business performance. The framework is described as follows

Based on the framework above, the hypothesis in this study are as follows:

H1: Operational performance supply chain which consist of structural capabilites, logistics capabilities, and technological capabilities partially influence the business performance of SMEs in Yogyakarta

H2: Operational performance supply chain which consist of structural capabilites, logistics capabilities, and technological capabilities together influence business performance of SMEs in Yogyakarta

\section{RESEARCH METHOD}

\section{Population and Sample}

Population is a generalization region that consist of: objects or subjects that have certain qualities and characteristics defined by the researcher to be studied and then drawn the conclusion (Sugiyono, 2010). In this study, the population is the entire SMEs in Yogyakarta, which is registered in the Office of $\mathrm{P}$ samples which are used 100 SMEs in Yogyakarta. The sampling technique used was simple random sampling that is taking members of the sample of the population that is done randomly without regard to strata that exist in the population (Sugiyono, 2010).

\section{Variables}

In this study the independent variable is the Supply Chain Operational Capability (X) consisting of structural capabilities (X1), logistics capabilities (X2), and the technological capabilities (X3). The dependent variable is the performance of business or business performance of SMEs (Y).

Structural capabilities often called human resourcesl. Zairi (1998) in Zulkifli (2010) emphasizes that people are the most important assets in an organization, and the success of an organization depends more on the people that are inside as compared to the products they produce. Indicators of structural capability are the organizational structure, extensive training, supervision of employees, ability of interaction, human resources and empowerment.

Logistics capability is the logistics activities that are good for developing a good distribution channel set up a distribution planning coherent and creating a delivery process that is smooth (Kallio 2000 in Zulkifli, 2010). Indicators of logistics capability are infrastructure logistics, location of suppliers, fast delivery, reliable delivery, cost of poor distribution, warehouse distribution and scope of distribution capability of technology is the ability of productive enterprises to face the technological development of industrial and technological change (Lall, 1993 in Zulkifli 2010).

Indicators of technological capabilities are as follows: information system, network information, the cost efficiency of information systems, sharing of information, the low rate of defective products, production capacity and just-in-time strategy.

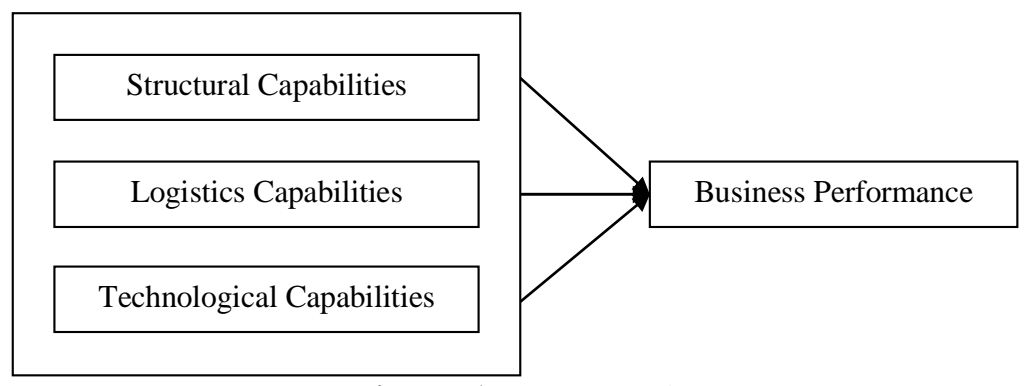

Figure 1Framewor k 
Business performance of the company is something that is produced by a company in a given period with reference to establish standards. The company's performance should be an outcome that can be measured and described the empirical conditions a company of any size agreed. Business performance refers to how well a company oriented to the market as well as the destination of the financial (Rahmasari, 2011). Indicators of business performance according to (Zulkifli, 2010) are as follows: The growth of the market share, development of revenue, Suppliers product quality, communication with suppliers, delivery performance, inventory levels of raw materials, lead time raw materials, product quality, level of assessment performance, employee skills, the department promotion, customer complaints, customer loyalty, or Awards achievements and Handling of customer orders.

\section{Data analysis technique}

Prior to the data analysis, it is earlier tested the validity and reliability. The validity of the test results showed that all the questions can be declared valid, and the reliability of the results of all the variables can be declared reliable. Furthermore, the data are tested which consist of classical assumption of multicollinearity, heteroscedasticity, normality and linearity.

To test the hypothesis of the study, the researcher uses simple linear regression analysis and multiple regression analysis. By using the $t$ test and $F$ test with a significance level of
$5 \%$, and the coefficient of determination (R2), the study is tested.

\section{RESULTS AND DISCUSSION}

\section{Characteristics of Respondents}

The primary data that have been collected by the researchers then analyzed. Analysis of the characteristics of respondents include the type of business which shows the type of the respondent's business namely services, manufacturing, furniture, culinary and convection respectively by 20 respondents or $20 \%$.

\section{Descriptive Analysis of the Research Va- riables}

The following are the results of the descriptive analysis of the answers given by respondents to the variables of this study. This analysis was conducted to obtain an image of the respondents' assessment of all the variables comprising structural capabilities, logistics capabilities, technology Capabilities and business performance. Descriptive results or assessment of respondents on the variables shown in the following table.

Based on the descriptive results of the assessment of respondents in the research variables showed that most respondents have given a fairly good assessment on the structural capabilities variables (3.26) and logistics capabilities (2.99), as well as good judgment on the technological capabilities of variables (3.99) and business performance (3.75).

Table 1: Characteristics of Respondents Based on The type of the Respondent's Business

\begin{tabular}{lll}
\hline The type of Business & Total & Percentage \\
\hline Services & 20 & $20 \%$ \\
Manufacturing & 20 & $20 \%$ \\
Furniture & 20 & $20 \%$ \\
Culinary & 20 & $20 \%$ \\
Convection & 20 & $20 \%$ \\
Total & 100 & $100 \%$ \\
\hline
\end{tabular}

Table 2: Descriptive Statistics of Research Variable

\begin{tabular}{llll}
\hline NO & Variables & Mean & Categories \\
\hline 1 & Structural capabilities & 3,26 & Average \\
2 & Logistics capabilities & 2,99 & Average \\
3 & Technological capabilities & 3,99 & Good \\
4 & Business performance & 3,75 & Good \\
\hline
\end{tabular}




\section{Validity and Reliability Test Results}

This analysis is used to measure how closely a test can perform the function of size. The higher validity of a device, the more precise the measuring device on target, and conversely the lower a measuring device, the more remote gauges in the target market. The technique used is Pearson Correlation.

Reliability testing was intended to determine the level of consistency of responses to questionnaires, so as to demonstrate the reliability of a measuring instrument. In this test, it used Cronbach's Alpha test. Cronbach's Alpha values > 0.6, the instrument can be expressed reliably. Validity and reliability of test results are shown in Table 2 below:

The validity of test results using the following criteria: $=95$ percent confidence level $(\alpha=5$ per cent $)$, the degree of freedom $(\mathrm{df})=$ $\mathrm{n}-2=100-2=98$, obtained $\mathrm{r}$ table $=0,197$. If $r_{\text {counted }}$ is greater than $r_{\text {table }}$ and the value of $r$ is positive, then the evidence is said to be a valid statement. Table 3 shows that all the indicators used to measure the variables used in this study had a greater correlation coefficient of $\mathrm{r}$ table $=$ 0,197 ( $r$ value table for $n=100$ ), so that all the indicators are valid.

Table 3: Results of Validity Test of Questionnaires

\begin{tabular}{|c|c|c|c|c|c|}
\hline Statement & $\mathbf{R}_{\text {counted }}$ & $\mathbf{r}_{\text {table }}$ & Description & Alpha Crobach & Description \\
\hline \multicolumn{4}{|c|}{ Structural Capabilities } & 0,612 & Reliable \\
\hline $\mathrm{X} 1.1$ & 0,512 & 0,197 & Valid & & \\
\hline $\mathrm{X} 1.2$ & 0,546 & 0,197 & Valid & & \\
\hline $\mathrm{X} 1.3$ & 0,432 & 0,197 & Valid & & \\
\hline X1.4 & 0,605 & 0,197 & Valid & & \\
\hline $\mathrm{X} 1.5$ & 0,710 & 0,197 & Valid & & \\
\hline $\mathrm{X} 1.6$ & 0.704 & 0,197 & Valid & & \\
\hline \multicolumn{4}{|c|}{ Logistic Capabilities } & 0,603 & Reliable \\
\hline $\mathrm{X} 2.1$ & 0,587 & 0,197 & Valid & & \\
\hline $\mathrm{X} 2.2$ & 0,736 & 0,197 & Valid & & \\
\hline $\mathrm{X} 2.3$ & 0,265 & 0,197 & Valid & & \\
\hline $\mathrm{X} 2.4$ & 0,772 & 0,197 & Valid & & \\
\hline $\mathrm{X} 2.5$ & 0,316 & 0,197 & Valid & & \\
\hline $\mathrm{X} 2.6$ & 0,579 & 0,197 & Valid & & \\
\hline $\mathrm{X} 2.7$ & 0,531 & 0,197 & Valid & & \\
\hline \multicolumn{4}{|c|}{ Technologic Capabilities } & 0.910 & Reliable \\
\hline $\mathrm{X} 3.1$ & 0,847 & 0,197 & Valid & & \\
\hline $\mathrm{X} 3.2$ & 0,849 & 0,197 & Valid & & \\
\hline X3.3 & 0,868 & 0,197 & Valid & & \\
\hline X3.4 & 0,719 & 0,197 & Valid & & \\
\hline X3.5 & 0,834 & 0,197 & Valid & & \\
\hline X3.6 & 0,799 & 0,197 & Valid & & \\
\hline \multicolumn{4}{|c|}{ Business Performance } & 0,692 & Reliable \\
\hline Y1 & 0,441 & 0,197 & Valid & & \\
\hline Y2 & 0,351 & 0,197 & Valid & & \\
\hline Y3 & 0,414 & 0,197 & Valid & & \\
\hline Y4 & 0,467 & 0,197 & Valid & & \\
\hline Y5 & 0,452 & 0,197 & Valid & & \\
\hline Y6 & 0,499 & 0,197 & Valid & & \\
\hline Y7 & 0,602 & 0,197 & Valid & & \\
\hline Y8 & 0,486 & 0,197 & Valid & & \\
\hline Y9 & 0,467 & 0,197 & Valid & & \\
\hline Y10 & 0,380 & 0,197 & Valid & & \\
\hline Y11 & 0,546 & 0,197 & Valid & & \\
\hline Y12 & 0,428 & 0,197 & Valid & & \\
\hline Y13 & 0,382 & 0,197 & Valid & & \\
\hline Y14 & 0,354 & 0,197 & Valid & & \\
\hline Y15 & 0,410 & 0,197 & Valid & & \\
\hline
\end{tabular}

Source: Primary Data, 2014 
From the reliability test results, it is obtained reliability coefficients for all variables used in this study is greater than the critical value is 0.6 so that it can be concluded that all the questions contained in the questionnaire of this study can be declared reliable. It means that this questionnaire had consistent results if done in time measurement and model or a different design.

\section{Hypothesis test result}

The test result on the multiple regression model that testing the supply chain operational capability influence, using the structural capability dimension, logistic capability and technological capability on the performance of SME businesses in Yogyakarta can be seen in the following table 5.

In this research used multiple linear regression equation model as follow:

$$
\mathrm{Y}=\mathrm{b}_{0}+\mathrm{b}_{1} \mathrm{X}_{1}+\mathrm{b}_{2} \mathrm{X}_{2}+\mathrm{b}_{3} \mathrm{X}_{3}+\mathrm{e}
$$

By paying attention of regression model and the result of the multiple linear regression, the equation of supply chain operational capability influence on SME business in Yogyakarta is created as follow:

$$
\mathrm{Y}=1,075+0,450 \mathrm{X}_{1}+0,163 \mathrm{X}_{2}+0,181 \mathrm{X}_{3}+\mathrm{e}
$$

Partial test to prove the influence of independent variable on dependent variable use ttest. By comparing the p-value (sig-t) with the tolerable significance level ( 5 percent), can be used to conclude the rejection or acceptance of the hypothesis. The structural capability variable has the p-value $(0,000)$. Therefore, the value of sig $t(0,000)<0,05$, so it can be concluded that Ho is rejected, which means that there is a positive significant influence of the structural capability in SME business performance in
Yogyakarta. Likewise the logistic capability variable has $\mathrm{p}$-value $(0,018)$. Therefore, the value of sig $t(0,018)<0,05$, therefore it can be concluded that Ho is rejected, which means there is a positive significant influence of logistic capability in the SME business performance in Yogyakarta. The influence of technological capability has p-value $(0,004)$. Therefore, the value of sig $t(0,004)<0,05$, therefore it can be concluded that $\mathrm{H}$ is rejected which means there is a positive significant influence of the technologial capability on the SME business pe $r$ formance in Yogyakarta.

From the result of the hypothesis testing above, it can be concluded that the supply chain operational capability that consists of structural capability, logistic capability and technological capability partially influence the performance of SME business in Yogyakarta so that the first hypothesis in this research is supported.

The result of $\mathrm{F}$ test is used to know the simultaneous influence of the supply chain operational capability on the performance of the SME business in Yogyakarta. The testing is performed by comparing the value of sig $\mathrm{F}_{\text {calcula- }}$ tion with the significance level of 5\%. The significance level used is 5 percent so that the value $\mathrm{f}$ sig $\mathrm{F}$ is 0.000 .

Based on the regression result table, it is known that the value of $F$ calculation is 45,890 with the p-value of 0,000 . In the significance level of $5 \%$, this result is significant because the $\mathrm{p}$ value $(0,000)<0,05$. It shws that the supply chain operational capability that consists $\mathrm{f}$ structural capability, logistic capability and technological capability has simultaneous influence on the SME business performance in Yogyakarta therefore the second hypothesis in this research is supported.

Table 5: Regression Result

\begin{tabular}{lllll}
\hline \multicolumn{1}{c}{ Independent Variable } & $\begin{array}{c}\text { Regression } \\
\text { coefficient }\end{array}$ & $\begin{array}{c}\text { Sig-t } \\
(\mathbf{p} \text {-value) }\end{array}$ & $\begin{array}{c}\text { Partial } \\
\text { correlation } \\
(\mathbf{r})\end{array}$ & $\begin{array}{c}\text { Partial corre- } \\
\text { lation coeffi- } \\
\text { cient }\left(\mathbf{r}^{2}\right)\end{array}$ \\
\hline Constant & 1,075 & & & \\
Structural Capability $\left(\mathrm{X}_{1}\right)$ & 0.450 & 0.000 & 0.539 & 0.291 \\
Logistic Capability $\left(\mathrm{X}_{2}\right)$ & 0.163 & 0.018 & 0.240 & 0.058 \\
Technological Capability $\left(\mathrm{X}_{3}\right)$ & 0.181 & 0.004 & 0.285 & 0.081 \\
\hline F calculation & 45,890 & & & \\
Sig-F & 0.000 & & & \\
Adjusted $\mathrm{R}^{2}$ & 0,576 & & & \\
\hline
\end{tabular}




\section{Determination coefficient}

In the regression analysis, there is a multiple determination coefficient can be used as a measure to state the compatibility of the regression line gained, the bigger the value of $R^{2}(R$ Square), the stronger the capability of regression model gained to explain the real condition. If $\mathrm{R}^{2}$ equal to 1 , the regression function $100 \%$ explains the variation of $\mathrm{Y}$ value, and conversely if the value is 0 , the model used is completely not close to $\mathrm{Y}$ value. The compatibility of the model is good if the value of $R^{2}$ close to 1

The result of determination coefficient (Adjusted $\mathrm{R}^{2}$ ) is 0,576 , therefore it an be said that 57,6 percent of the SME business performance is influenced by supply chain operational capability that consists of structural capability, logistic capability, and technological capability. While the remaining 42.4 percent is influenced by other variables not included into the research model.

\section{Partial determination coefficient correlation analysis}

To know the supply chain operational capability factor consists of structural capability, logistic capability and technological capability, we use the influence weight which is shown by the partial determination coefficient. The biggest result of the partial determination coefficient testing $\left(r^{2}\right)$ is shw by the structural capability variable $\left(X_{1}\right)$ which is 0,291 or 29,1 percent. Therefore, structural capability variable $\left(\mathrm{X}_{4}\right)$ has the biggest influence on the SME business performance in Yogyakarta.

\section{DISCUSSION}

Based on the t-test it can be concluded that the structural capability has positive influence on the SME business performance. It shows that the bigger the company's structural capability, that consists of organizational structure, extensive training, employee monitoring, interaction capability, human resources, and empowerment will improve the company's business performance. The human resources capability can be seen from the responsibility level given $t$ them, in which the responsibilities are explained in the job description. With a clear job description, it can help one to perform their duty well. In performing the function of each employee must have the skills to improve the performance of the company.

Logistic capability has a positive influence on the SMEs business performance. IT shows that the bigger the logistic capability of a company, that consists of logistic infrastructure, supplier location, fast delivery, reliable delivery, low distribution cost, distribution warehouse, and distribution scope will improve the company's business performance. More innovated company in managing their logistic capability can improve a more responsive organization operational, which in the end will improve the company's service and decrease the logistic problems. Cho, Ozment, and Sink (2008) stated that the logistic capability of the company in improving performance must be supported by the third party in this term is the logistic supplier or commonly known as 3PL.

Technological capability has positive influence on the SME business performance. IT shows that if the company improves the company's capability that consists of information system, information network, information system cost efficiency, information sharing, the low level of defective products, production capacity, and just-in-time strategy will improve the SME business performance value. Based $n$ t-test, it can be concluded that technological capability has a positive influence on SME business performance. IT shows that if the company improve the company's capability that consists of information system, information network, information system cost efficiency, information sharing, the low level of defective products, production capacity, and just-intime strategy will improve the value of SME business performance.

In this term, technological capability is the most important aspect of the information technology will help the improvement of information quality. One of the examples of information technology is computer that can help accelerate the work being done, by using computer, the work will be more accurate and consistent in calculation compared to manual system so that the company's performance will be improved.

There is a simultaneous influence of the supply chain operational capability that consists of structural capability, logistic capability and technological capability on the SME business performance in Yogyakarta therefore 
the second hypothesis in this research is supported. It shows that higher the supply chain operational capability, the higher the SME business performance in Yogyakarta. The value of $\mathrm{F}$ calculation is 45,890 with the p-value 0,000 . In te significance level $5 \%$, this result is significant because the p-value $(0,000)<0,05$. It shows that the supply chain operational capability that consists of structural capability, logistic capability and technological capability simultaneously influence the SME business performance in yang terdiri kapabilitas struktural, kapabilitas logistik dan kapabilitas teknologi berpengaruh secara simultan terhadap kinerja bisnis SMEs di Yogyakarta.

These results are in compliance with the result of the research by Zulkifli (2010) that shows that the structural capability, logistic capability and technological capability on the SME business performance.

\section{CONCLUSION}

Based on the result of the research that has been explained in the previous chapter, it can be concluded that: 1) There is a simultaneous influence of the supply chain operational capability that consists of structural capability, logistic capability and technological capability on the SME business performance in Yogyakarta therefore the first hypothesis in this research is supported. It shows that the higher supply chain operational capability will improve the SME business performance in Yogyakarta. 2) There is partial influence of the supply chain operational capability that consists of structural capability, logistic capability and technological capability on the SME business performance in Yogyakarta therefore the second hypothesis in this research is supported. It means that the higher the supply chain operational capability that consists of structural capability, logistic capability and technological capability will improve SME business performance in Yogyakarta therefore the second hypothesis of this research is supported.

\section{MANAGERIAL IMPLICATION}

Based on the conclusion above, the company can manage their supply chain operational capability as follows: 1) With the supply chain operational capability consists of structural capability, logistic capability and technological capability simultaneously and partially influence the SME business performance, the SME must consider those factors in the effort of improving business performance through empowerment of organization culture, employee training, and information system development. 2) From the descriptive analysis, it can be concluded that structural capability is the variable which is valued the lowest by the respondents. Based on this, the company must improve their capability in organizational structure, extensive training, employee monitoring, interaction capability, human resources and empowerment.

\section{REFERENCES}

Bowersox, D. J. and Daugherty, P. J. 1995. Logistics paradigms: The impact of information technology. Journal of Business Logistics. 16(1). 65-80.

Cho, J. J.-K., Ozment, J. and Sink, H. 2008. Logistics capability, logistics outsourcing and firm performance in an ecommerce market. International Journal of Physical Distribution \& Logistics Management. 38(5). 336-359.

Feng, M., Terziovski, M. and Samson, D. 2008. Relationship of ISO 9001:2000 quality system certification with operational and business performance: A survey in Australia and New Zealand-based manufacturing and service companies. Journal of Manufacturing Technology Management. 19(1). 22-37.

Heizer, Jay dan Barry Render. 2005. Manajemen Operasi,Edisi 7, Buku 1. Jakarta.Penerbit Salemba Empat.

Indrajit R. E., dan R. Djokopranoto. 2002. Konsep Manajemen Supply Chain: Cara Baru Memandang Mata Rantai Penyediaan Barang. Jakarta. PT Grasindo.

Instruksi Presiden Republik Indonesia Nomor 10 Tahun 1999 Tentang Pemberdayaan Usaha Menengah

Levi, David Simchi, Philip Kamin Sky and Edith Simchi Levi. 2000. Designing And Managing The Supply Chain : Concept, Strategies And Case Studies. Singapore. Irwin McGraw-Hill 
Rahmasari, Lisda. 2011. Pengaruh SCM terhadap kinerja perusahaan dan keunggulan bersaing (Studi kasus pada industri kreatif di provinsi Jawa Tengah). $M a$ jalah Ilmiah Informatika. 2(3). September 2011.

Sriyana, Jaka. 2010. Strategi Pengembangan Usaha Kecil dan Menengah (SMEs): Studi Kasus di kabupaten Bantul. Simposium Nasional 2010: Menuju Purworejo Dinamis dan Kreatif.

Sugiyono. 2010. Metode Penelitian Bisnis, Bandung. ALFABETA.

Suhartati, Titi, dan Hilda Rosietta. 2007. Pengaruh strategi bersaing terhadap hubungan antara $S C M$ dan kinerja (Studi pada perusahaan manufaktur yang terdaftar di Bei). Simposium Nasional Akuntansi.

Undang Undang No. 9 Tahun 1995 Tentang: Usaha Kecil
Undang-Undang Nomor 20 tahun 2008 Tentang Usaha Mikro, Kecil, dan Menengah

Wood, E. H. 2006. The internal predictors of business performance in small firms. Journal of Small Business and Enterprise Development. 13(3). 441-452.

Yong, T., Shi-hua, M. and Feng-mei, G. 2007. Empirical study on impact of logistics operations capability on supply chain performance. The 3rd International Conference on Wireless Communications, Networking, and Mobile Computing (WiCOM) 2007 (pp. 4760-4766). Shanghai, P.R. China.

Zulkifli, Siti Nur Aisyah. 2010. The impact of supply chain operational capabilities on business performance of small and medium enterprises in Malaysia: A Preliminary Analysis. International Journal of Business and Management Science 3(2) . 147-168. 